\title{
Physicochemical Properties and Fungicidal Efficacy of Mancozeb Commercial Products in Egypt
}

\author{
Ahmed M. El-Bakry ${ }^{1}$ Soad M. Ahmed ${ }^{1}$, Farid S. Sabra ${ }^{2}$, Shehata M. I. Kassem ${ }^{1}$, Elham A. Sammour ${ }^{3}$, \\ Samir A. M. Abdelgaleil ${ }^{1}$
}

\begin{abstract}
Mancozeb is a wide spectrum contact fungicide for use on a numerous variety of vegetables and ornamentals worldwide. In this study, the physicochemical properties of six commercial mancozeb $(80 \%)$ wettable powder products, Anadol, Dithane Dicozeb, Mancozan, Manco and Tridex, were determined as described by Collaborative International Pesticides Analytical Council (CIPAC) and World Health Organization (WHO). The antifungal activity of mancozeb products was evaluated against four plant pathogenic fungi, namely Alternaria alternata, Phytophthora infestans, Fusarium oxysporum and Pythium debaryanum in vitro. The results of physicochemical tests showed that all mancozeb products passed suspensibility and wettability tests. In foam formation test, all the products passed the test except Anadol which failed in both CIPAC and WHO methods, while Manco failed in WHO method. Among the six tested mancozeb products, Tridex was the only one that passed alkalinity test. Although the six mancozeb products were formulated as wettable powder with the same concentration of active ingredient $(80 \%)$ the antifungal activity of the products were markedly differed. Tridex exhibited the strongest antifungal activity against three of the four tested fungi $A$. alternata, $F$. oxysporum and $P$. infestans, while, Dithane was the most effective fungicide against $P$. debaryanum. $A$. alternata was the most sensitive fungi to all of the tested fungicides, while $F$. oxysporum and $P$. debaryanum displayed the lowest sensitivity. The results of this study indicated that some of mancozeb commercial formulations in the Egyptian markets were not matched with CIPAC and WHO specifications and the antifungal activity was strongly varied based on the manufacturing company.
\end{abstract}

Keywords: physicochemical properties, mancozeb formulations, antifungal activity

\section{INTRODUCTION}

Pesticide formulations can undergo chemical and physical changes on storage. The rate at which these changes occur depends on the nature of the active constituent(s), the formulation type, the packaging and the storage conditions. The product remains fit for use as long as these changes have no adverse effects on application, biological performance, and the safety of operators, consumers and the environment. To ensure the quality of the formulations, the physico-chemical tests on formulations must be carried out as described by Collaborative International Pesticides Analytical Council (CIPAC) and World Health Organization (WHO). These tests are varied with formulation type and include emulsion stability tests, acidity and alkalinity, suspensibility tests, spontaneous emulsification tests, storage stability tests and others (Shafik and Abu Elamayem, 1967; Anonymous, 1970 and 1979; Niessen, 1978 Seaman, 1990; Mookerjee, 1984).

Mancozeb, introduced in 1962, is a broad spectrum contact fungicide with a protective action which belongs to the dithiocarbamates family of chemicals. Mancozeb is applied as a spray and is supplied as wettable powders and granules which are mixed with water. Mancozeb alone is used on a number of crops world-wide to control a number of fungal diseases, such as Anthracnose, Pythium blight, leaf spot, downy mildew, Botrytis, rust and scab. It is also effective against Algae. It is approved for use on a huge variety of crops, including potatoes, oilseed rape, lettuce, wheat, apples, tomatoes, table grapes, wine grapes, bulb onions, carrot, parsnip, shallot, durum wheat and leeks. Mancozeb acts by disrupting lipid metabolism (Patsakos et al., 1992; Dillard et al., 1997; Secor and Gudmestad, 1999; Wong and Wilcox, 2001; Allen et al., 2004; Gutierrez Chapin et al., 2006).

The purpose of this work was to measure the physicochemical parameters (i.e. suspensibility, wetting time, foam formation and alkalinity) of six mancozeb ( $80 \%$ wettable powder) commercial products available in Egypt, to ensure their conformity with the standard specifications of WHO and CIPAC. In vitro fungicidal activity of these products was also evaluated against four plant pathogenic fungi, Alternaria alternata, Phytophthora infestans, Fusarium oxysporum and Pythium debaryanum.

\footnotetext{
${ }^{1}$ Department of Pesticide Chemistry, Faculty of Agriculture (Elshatby) Alexandria University, Alexandria 21545, Egypt

${ }^{2}$ Department of Plant Production and Protection

Collage of Agriculture and Veterinary Medicine

Qassim University, Saudi Arabia

${ }^{3}$ Department of Pests and Plant Protection,

National Research Centre, Dokki, Giza, Egypt

Received November 17, 2012, Accepted December 27, 2012.
} 


\section{MATERIALS AND METHODS}

\section{Fungi}

Four phytopathogenic fungi species, Alternaria alternata, Phytophthora infestans, Fusarium oxysporum and Pythium debaryanum, were used. The fungi were obtained from the Fungicide Bioassay Laboratory, Department of Pesticide Chemistry, Faculty of Agriculture, Alexandria University. The fungi were maintained during the course the experiments on potato dextrose agar medium (PDA: potato 200, dextrose 20 and agar $15 \mathrm{~g} / \mathrm{L}$ in distilled water) at $25{ }^{\circ} \mathrm{C}$.

\section{Mancozeb and its formulation}

Sixmancozeb,1,2ethanediylbis[carbamodithioato]] (2-)]manganese mixture with [[1,2ethanediylbis[carbamodithioate]](2-)]zinc, (80\% WP) commercial formulations were purchased form the local market in Alexandra and Cairo. These products were Anadol (El-Helb Misr for Pesticides and Chemicals Company), Dithane (Consukorra Chemicals Company), Dicozeb (National for Agrochemicals), Mancozan (Kafr El-Zayat Pesticides and Chemicals Company), Manco (Misr Agriculture Develoment Company) and Tridex (United Phosphorus Ltd. Bharuch).

\section{Physicochemical properties of mancozeb products}

\subsection{Suspensibility test}

The method was carried out as described by CIPAC (Anonymous, 1970). Sample (6.25 g, a) of mancozeb product $(80 \% \mathrm{WP}$ ) was weighed and added slowly to a beaker containing $50 \mathrm{ml}$ of tested water (distilled water, soft water and hard water (each litre contains $0.304 \mathrm{~g}$ of anhydrous calcium chloride and $0.139 \mathrm{~g}$ magnesium chloride hexahydrate)) at $30 \pm 1{ }^{\circ} \mathrm{C}$, while swirling by hand in a circular motion at a rate of 120 rounds per minute for $2 \mathrm{~min}$. The suspension was left to stand for a further $13 \mathrm{~min}$ in a water bath at the same temperature. The suspension was transferred quantitatively to a measuring cylinder $(250 \mathrm{ml})$ which has previously been brought to a temperature of $30{ }^{\circ} \mathrm{C}$. Tested water was made up to $250 \mathrm{ml}$ at $30 \pm 1^{\circ} \mathrm{C}$, and then the stopper was inserted. The cylinder was inverted upside down 30 times in one minute. The cylinder was placed in the water bath without shaking. After $30 \mathrm{~min}, 225 \mathrm{ml}$ (9/10ths) of the contents was removed in 10 to $15 \mathrm{sec}$ using the suction tube, without shaking or stirring the content of the cylinder. The tip of the tube should be only a few $\mathrm{mm}$ below the surface of the liquid. The remaining $25 \mathrm{ml}$ was filtered, dried and weighted (b). Suspensibility was calculated from the following equation:

$$
\text { Suspensibility }(\%)=\frac{(\mathrm{a}-\mathrm{b})}{\mathrm{a}} \times \frac{10}{9} \times 100
$$

where $a$ is weight of the sample taken and $b$ is weight of the sample in the $25 \mathrm{ml}$ remaining in the cylinder. Suspensibility percentage must be more than 50 to pass the test.

\subsection{Wetting test}

The method was carried out according to CIPAC specifications (Anonymous, 1970). One hundred $\mathrm{ml}$ of each type of water was poured into the beaker and $5 \mathrm{~g}$ of a representative sample of mancozeb product ( $80 \%$ WP) was weighed out, taking care that it remained in a noncompacted state. The powder was added at once, by dropping it on the water, from a position level with the rim of the beaker, without undue agitation of the liquid surface. When the powder was added, a stop watch was started and the time taken was recorded (to the nearest second) for the sample to become completely wetted (a film of fine particles remaining on the surface may be neglected). The time required for complete wetting of the powder was reported as the wetting time. Wetting time of mancozeb wettable powder formulations should not exceed $60 \mathrm{sec}$.

\subsection{Foam formation test using CIPAC and WHO methods}

\subsubsection{CIPAC method}

The sample of mancozeb product was weighed (5 g) and added to $(95 \mathrm{ml})$ tested water (distilled, soft and hard waters) in measuring cylinder $(100 \mathrm{ml})$ and made up to the mark. The cylinder was stoppered and inverted 30 times. The cylinder was stand on the bench and left undisturbed for one minute and then the foam layer was measured. Foam layer of mancozeb wettable powder formulations should not exceed $25 \mathrm{ml}$.

\subsubsection{WHO method}

The test was conducted as described by WHO (Anonymous, 1979). Into $250 \mathrm{ml}$ beaker having an internal diameter of $6-6.5 \mathrm{~cm}$ and $100 \mathrm{ml}$ calibration mark, $75-80 \mathrm{ml}$ of the tested water (distilled, soft and hard waters) was poured and brought to a temperature of $30 \pm 1{ }^{\circ} \mathrm{C}$. The sample of mancozeb product $(5 \mathrm{~g})$ was added, while stirring with a glass rod, 4-6 $\mathrm{mm}$ in diameter, at about four revolutions/second. The beaker contents were completed to $100 \mathrm{ml}$ by addition of the tested water, while the stirring is continuous. The beaker contents were poured immediately into a clean, dry, graduated $100 \mathrm{ml}$ cylinder. The stirring time was three minutes from the beginning of the sample addition until pouring into the $100 \mathrm{ml}$ cylinder. The cylinder was stand on the bench and left undisturbed for 5 minutes and examined for foam formation (the foam layer should not exceed five $\mathrm{ml}$ for passing the foam test). 


\subsection{Alkalinity determination}

Sample $(10 \mathrm{~g})$ was weighed and suspended in $100 \mathrm{ml}$ of distilled water and titrated with hydrochloric acid solution $(0.02 \mathrm{M} / \mathrm{L})$, in the presence of methyl red as indicator (Anonymous, 1970). Distilled water was used as blank sample. Alkalinity was calculated as $\% \mathrm{NaOH}$ using the following equation:

Alkalinity $=0.008 \times(\mathrm{V} 1-\mathrm{V} 2)$

where: $\mathrm{V} 1$ is volume $(\mathrm{ml})$ of hydrochloric acid solution $(0.02 \mathrm{M} / \mathrm{L})$ consumed for pesticide formulation sample. $\mathrm{V} 2$ is volume $(\mathrm{ml})$ of hydrochloric acid solution $(0.02$ $\mathrm{M} / \mathrm{L}$ ) consumed for blank sample (alkalinity calculated as $\% \mathrm{NaOH}$ should not exceed 0.05 to pass the test).

\subsection{Tropical (heat) storage test}

The sample (200 g) was put into beaker and spread it, without using any pressure, in a smooth even layer of constant thickness. The disc was placed on the surface of the powder in the beaker, and put in the oven at $54 \pm$ $1{ }^{\circ} \mathrm{C}$ for 14 days. The beaker was allowed to cool in the desiccator.

\subsection{In vitro antifungal assay}

The mycelial radial growth inhibition technique was used to evaluate the fungicidal activity of mancozeb different products against $A$. alternata, $F$. oxysporum, $P$. debrianum and $P$. infestans as described by Zambonelli et al. (1996). First, the six different mancozeb products were tested against the four tested fungi at concentration of $500 \mathrm{mg} / 1$. Fungicides caused mycelial growth inhibition greater than $50 \%$ were further evaluated at a series of concentration of $5,10,25,50,100,250$ and $500 \mathrm{mg}$ a.i./L. Appropriate volumes of the stock solutions of the tested fungicides in distilled water were added to Potato Dextrose Agar (PDA) medium immediately before pouring into the Petri dishes $(9.0 \mathrm{~cm}$ in diameter) at $40-45^{\circ} \mathrm{C}$. Each concentration was tested in triplicate. Parallel controls were maintained with distilled water mixed with PDA. The discs of mycelial felt $(0.5 \mathrm{~cm}$ diameter $)$ of the plant pathogenic fungi, taken from 8-day-old cultures on PDA plates, were transferred aseptically to the centre of Petri dishes. The treatments were incubated at $25^{\circ} \mathrm{C}$ in the dark. Colony growth diameter was measured after the fungal growth in the control treatment had almost completely covered the Petri dishes. The percentage of mycelial growth inhibition was calculated according to the equation of Topps and Wain (1957) as follows:

$$
\% \mathrm{I}=[(\mathrm{DC}-\mathrm{DT}) / \mathrm{DC}] \times 100
$$

where: \% I is percentage of mycelial growth inhibition, DC and DT are average diameters of fungal colony of control and treatment, respectively. The concentration of fungicides that inhibiting the fungi mycelial growth by $50 \%\left(\mathrm{EC}_{50}\right)$ was determined by a linear regression method (Finney, 1971).

\section{RESULTS AND DISCUSSION}

\section{Physico-chemical properties of mancozeb products}

Suspensibility data of mancozeb different products before and after heat storages using distilled, soft and hard waters are summarized in Table 1. The results showed that maximum suspensibility was observed in hard water, followed by soft and distilled waters. Heat storage improved suspensibility for all mancozeb products. All mancozeb products gave a good suspensibility before and after heat storages using the three types of waters. The susbensibility ranged from $72.1 \%$ to $82.6 \%$ for all products, except Anadol which ranged from $60.7 \%$ to $72.8 \%$. On the other hand, wettability results of mancozeb products before and after heat storages using distilled, soft and hard waters are shown in Table 2. Heat storage improved wetting time. The short wetting times were observed in distilled water, followed by hard and soft waters. All mancozeb products passed the test in the three types of waters. Mancozeb products were completely wetted in less than one min. Tridex revealed the best wetting time of $7.6 \mathrm{sec}$ after heat tropical storage using distilled water.

Table 1. Suspensibility of mancozeb different products before and after heat storages using CIPAC method

\begin{tabular}{|c|c|c|c|c|c|c|c|}
\hline \multirow{3}{*}{ Product } & \multirow{3}{*}{ M. D } & \multicolumn{6}{|c|}{ \% suspensibility } \\
\hline & & \multicolumn{3}{|c|}{ Before storage } & \multicolumn{3}{|c|}{ After heat storage } \\
\hline & & D.W & S.W & H.W & D.W & S.W & H.W \\
\hline Anadol & $7 / 2010$ & 60.7 & 64 & 65.7 & 69.3 & 71.1 & 72.8 \\
\hline Dicozeb & $8 / 2010$ & 72.8 & 74.2 & 75.1 & 78.6 & 80.4 & 79.5 \\
\hline Dithane & $1 / 2010$ & 72.4 & 74.6 & 76 & 77.7 & 79.1 & 80 \\
\hline Manco & $2 / 2010$ & 72.1 & 73.7 & 75.1 & 77.3 & 78.6 & 80 \\
\hline Mancozan & $7 / 2010$ & 72.4 & 73.7 & 74.6 & 76.4 & 78.2 & 79.1 \\
\hline Tridex & $4 / 2010$ & 73.7 & 75.1 & 76.8 & 80 & 81.7 & 82.6 \\
\hline
\end{tabular}

M. $\mathrm{D}=$ manufacturing date.

Expire date after two years from production.

Experimental date $=4 / 2011$.

D.W = distilled water; $\mathrm{S} . \mathrm{W}=$ soft water; $\mathrm{H} . \mathrm{W}=$ hard water. 
Table 2. Wettability of mancozeb different products before and after heat storages using CIPAC method

\begin{tabular}{lccccccc}
\hline \multirow{2}{*}{\multicolumn{1}{c}{ Product }} & \multirow{2}{*}{ M. D } & \multicolumn{6}{c}{ Wetting time (sec) } \\
\cline { 3 - 8 } & & \multicolumn{3}{c}{ Before storage } & \multicolumn{3}{c}{ After heat storage } \\
\cline { 2 - 8 } & $7 / 2010$ & D.W & S.W & H.W & D.W & S.W & H.W \\
\hline Anadol & 20.6 & 24 & 22.3 & 14.3 & 18 & 18 \\
\hline Dicozeb & $8 / 2010$ & 25 & 29 & 26.3 & 21 & 24.6 & 24.3 \\
\hline Dithane & $1 / 2010$ & 22 & 26 & 23 & 16 & 19 & 18 \\
\hline Manco & $2 / 2010$ & 22.6 & 27.6 & 23.3 & 20 & 24.3 & 23.3 \\
\hline Mancozan & $7 / 2010$ & 42 & 44 & 29.6 & 16 & 19.6 & 18.3 \\
\hline Tridex & $4 / 2010$ & 11 & 14 & 14 & 7.6 & 11.3 & 10.3 \\
\hline
\end{tabular}

M. D = manufacturing date.

Expire date after two years from production.

Experimental date $=4 / 2011$.

D.W = distilled water; $\mathrm{S} . \mathrm{W}=$ soft water; $\mathrm{H} . \mathrm{W}=$ hard water.

The results of foam formation CIPAC test revealed that the foam layers formed before storage were less than those formed after heat storage (Table 3). All mancozeb products passed the test before and after heat tropical storage in the three types of waters as the foam layers were less than $25 \mathrm{ml}$, except Anadol after heat storage using soft water (foam layer was $26 \mathrm{ml}$ ). Tridex revealed very low foam layers before storage (3.3-4.8 $\mathrm{ml})$ and after heat tropical storage $(2-4 \mathrm{ml})$. Similarly, results of WHO foam test showed that foam layers formed before storage were less than those formed after heat storage (Table 3). All mancozeb different products passed the test before storage using the three types of waters as the foam layers were less than $5 \mathrm{ml}$, except Anadol (foam layers were 6 and $5.3 \mathrm{ml}$ using soft and hard waters, respectively). Anadol and Manco failed the foam test after heat storage as foam layers were 6.3 and $5.6 \mathrm{ml}$ of Anadol using soft and hard waters, respectively, and $5.3 \mathrm{ml}$ of Manco using soft water.

Tridex did not show any foam layers before and after heat tropical storage using three types of waters. Matthews (1985) reported that $10 \mathrm{ml}$ of foam should remain in a $100 \mathrm{ml}$ graduated cylinder 5 minutes after mixing of the sample of spray at field strength.

The results of alkalinity test (Table 4) revealed all mancozeb different products failed the test before and after heat storages, except Tridex, where alkalinity calculated as $\% \mathrm{NaOH}$ were 0.03 and 0.04 before and after heat tropical storage, respectively.

\section{In vitro antifungal activity of mancozeb products against plant pathogenic fungi}

The inhibitory effect of mancozeb (80\% WP) different products on the mycelial growth was evaluated against four plant pathogenic fungi, A. alternata, $P$. infestans, $F$. oxysporum and $P$. debaryanum. The values of $\mathrm{EC}_{50}, 95 \%$ confidence limits and other parameters generated form regression lines are shown in Table 5.

\section{Table 3. Foam formation of mancozeb different products before and after heat storages using CIPAC and WHO methods}

\begin{tabular}{|c|c|c|c|c|c|c|c|c|c|c|c|c|c|}
\hline \multirow{4}{*}{ Product } & \multirow{4}{*}{ M. D } & \multicolumn{12}{|c|}{ Foam $(\mathrm{ml})$} \\
\hline & & \multicolumn{6}{|c|}{ CIPAC } & \multicolumn{6}{|c|}{ WHO } \\
\hline & & \multicolumn{3}{|c|}{ Before storage } & \multicolumn{3}{|c|}{ After heat storage } & \multicolumn{3}{|c|}{ Before storage } & \multicolumn{3}{|c|}{ After heat storage } \\
\hline & & D.W & S.W & H.W & D.W & S.W & H.W & D.W & S.W & H.W & D.W & S.W & H.W \\
\hline Anadol & $7 / 2010$ & 21 & 23 & 22 & 23.6 & 26 & 23.6 & 3.6 & 6 & 5.3 & 4 & 6.3 & 5.6 \\
\hline Dicozeb & $8 / 2010$ & 17 & 22 & 19 & 20.6 & 23.6 & 20.3 & 2.3 & 4 & 3 & 3 & 4.3 & 3.6 \\
\hline Dithane & $1 / 2010$ & 17 & 20 & 18 & 20 & 22.3 & 19.3 & 2 & 3.6 & 2.6 & 2.6 & 3.6 & 3.3 \\
\hline Manco & $2 / 2010$ & 19 & 21.3 & 20.3 & 20.3 & 23.6 & 21.3 & 2.8 & 4.6 & 4 & 3.3 & 5.3 & 4.6 \\
\hline Mancozan & $7 / 2010$ & 14.3 & 18 & 16 & 17 & 20.3 & 18.6 & 1.6 & 3 & 2 & 2 & 3 & 2.3 \\
\hline Tridex & $4 / 2010$ & 2.3 & 4 & 2 & 3.3 & 4.8 & 3.3 & 0 & 0 & 0 & 0 & 0 & 0 \\
\hline
\end{tabular}

M. $\mathrm{D}=$ manufacturing date.

Expire date after two years from production.

Experimental date $=5 / 2011$.

$\mathrm{D} . \mathrm{W}=$ distilled water; $\mathrm{S} . \mathrm{W}=$ soft water; $\mathrm{H} . \mathrm{W}=$ hard water. 
Table 4. Alkalinity of mancozeb different products before and after heat storages using CIPAC method

\begin{tabular}{lccc}
\hline \multirow{2}{*}{ Product } & \multirow{2}{*}{ M. D } & \multicolumn{3}{c}{ \% NaOH } \\
\cline { 3 - 4 } & & Before storage & After heat storage \\
\hline Anadol & $7 / 2010$ & 0.06 & 0.1 \\
\hline Dicozeb & $8 / 2010$ & 0.06 & 0.09 \\
\hline Dithane & $1 / 2010$ & 0.07 & 0.12 \\
\hline Manco & $2 / 2010$ & 0.08 & 0.1 \\
\hline Mancozan & $7 / 2010$ & 0.06 & 0.09 \\
\hline Tridex & $4 / 2010$ & 0.03 & 0.04 \\
\hline
\end{tabular}

$\mathrm{M} . \mathrm{D}=$ manufacturing date.

Expire date after two years from production.

Experimental date $=7 / 2011$

Table 5. Comparative in vitro antifungal activity of mancozeb $(80 \% \mathrm{WP})$ different products against plant pathogenic fungi

\begin{tabular}{|c|c|c|c|c|c|c|c|}
\hline \multirow[t]{2}{*}{ Product } & \multirow[t]{2}{*}{ Fungus } & \multirow{2}{*}{$\begin{array}{c}\mathbf{E C}_{50}{ }^{a} \\
(\mathrm{mg} / \mathrm{L})\end{array}$} & \multicolumn{2}{|c|}{$\begin{array}{l}95 \% \text { Confidence } \\
\text { limits }(\mathrm{mg} / \mathrm{L})\end{array}$} & \multirow{2}{*}{$\begin{array}{l}\text { Slope } \\
\pm \text { SE }^{b}\end{array}$} & \multirow{2}{*}{$\begin{array}{c}\text { Intercept } \\
\quad \pm \mathrm{SE}^{\mathrm{c}}\end{array}$} & \multirow[t]{2}{*}{$\left(\chi^{2}\right)^{\mathrm{d}}$} \\
\hline & & & Lower & Upper & & & \\
\hline \multirow{4}{*}{ Anadol } & A. alternata & 54.1 & 25.7 & 119.6 & $1.08 \pm 0.08$ & $-1.88 \pm 0.15$ & 28.75 \\
\hline & P. infestans & 65.1 & 50.2 & 85.8 & $0.86 \pm 0.07$ & $-1.57 \pm 0.14$ & 5.19 \\
\hline & F. oxysporum & 194.4 & 146.5 & 275.3 & $0.94 \pm 0.08$ & $-2.17 \pm 0.16$ & 5.41 \\
\hline & P. debaryanum & 74.9 & 58.4 & 97.8 & $0.92 \pm 0.08$ & $-1.73 \pm 0.14$ & 6.73 \\
\hline \multirow{4}{*}{ Dithane } & A. alternata & 54.2 & 30.6 & 99.1 & $1.22 \pm 0.08$ & $-2.12 \pm 0.15$ & 22.14 \\
\hline & P. infestans & 76.0 & 58.8 & 100.5 & $0.88 \pm 0.07$ & $-1.66 \pm 0.14$ & 6.74 \\
\hline & F. oxysporum & 82.9 & 60.3 & 118.6 & $0.7 \pm 0.07$ & $-1.35 \pm 0.14$ & 2.43 \\
\hline & P. debaryanum & 68.4 & 52.5 & 90.7 & $0.86 \pm 0.07$ & $-1.57 \pm 0.14$ & 6.63 \\
\hline \multirow{4}{*}{ Dicozeb } & A. alternata & 40.2 & 22 & 70.9 & $1.13 \pm 0.08$ & $-1.82 \pm 0.15$ & 19.4 \\
\hline & P. infestans & 59.1 & 37.8 & 95 & $0.91 \pm 0.08$ & $-1.62 \pm 0.14$ & 8.96 \\
\hline & F. oxysporum & 71.4 & 52.2 & 100.5 & $0.71 \pm 0.07$ & $-1.31 \pm 0.13$ & 2.85 \\
\hline & P. debaryanum & 146.2 & 109.4 & 207.3 & $0.85 \pm 0.08$ & $-1.85 \pm 0.15$ & 5.88 \\
\hline \multirow{4}{*}{ Manco } & A. alternata & 57.6 & 32.2 & 107.5 & $1.24 \pm 0.08$ & $-2.18 \pm 0.16$ & 23.41 \\
\hline & P. infestans & 68.5 & 52.6 & 90.7 & $0.86 \pm 0.07$ & $-1.58 \pm 0.14$ & 6.12 \\
\hline & F. oxysporum & 129.1 & 93.9 & 190.1 & $0.74 \pm 0.07$ & $-1.57 \pm 0.14$ & 0.97 \\
\hline & P. debaryanum & 79.1 & 60.9 & 105.2 & $0.87 \pm 0.07$ & $-1.66 \pm 0.14$ & 6.07 \\
\hline \multirow{4}{*}{ Mancozan } & A. alternata & 57.2 & 45.8 & 71.9 & $1.04 \pm 0.08$ & $-1.84 \pm 0.15$ & 4.31 \\
\hline & P. infestans & 52.1 & 39.8 & 68.3 & $0.85 \pm 0.07$ & $-1.46 \pm 0.14$ & 7.68 \\
\hline & F. oxysporum & 115.5 & 62.6 & 284.9 & $0.62 \pm 0.07$ & $-1.28 \pm 0.14$ & 8.51 \\
\hline & P. debaryanum & 88 & 68.3 & 116.4 & $0.91 \pm 0.08$ & $-1.78 \pm 0.14$ & 5.46 \\
\hline \multirow{4}{*}{ Tridex } & A. alternata & 29.9 & 16.2 & 50.2 & $1.1 \pm 0.08$ & $-1.63 \pm 0.14$ & 16.62 \\
\hline & P. infestans & 39.97 & 16.81 & 87.92 & $0.99 \pm 0.08$ & $-1.59 \pm 0.14$ & 27.47 \\
\hline & F. oxysporum & 42.28 & 30.03 & 58.75 & $0.68 \pm 0.07$ & $-1.1 \pm 0.13$ & 4.9 \\
\hline & P. debaryanum & 93.45 & 70.15 & 129.51 & $0.79 \pm 0.07$ & $-1.57 \pm 0.14$ & 7.96 \\
\hline
\end{tabular}


In general, Dithane, Dicozeb, Manco and Tridex showed the strongest antifungal activity against the fungus $A$. alternata. Tridex revealed the strongest antifungal activity against $F$. oxysporum and $P$. infestans, while, Dithane was the most effective fungicide against the fungus $P$. debaryanum. Tridex was the most effective fungicide, as it revealed the strongest antifungal activity against three of four tested fungi. Anadol showed the highest antifungal activity against the fungus A. alternata $\left(\mathrm{EC}_{50}=54.1 \mathrm{mg} / \mathrm{L}\right)$, followed by $P$. infestans $\left(\mathrm{EC}_{50}=65.13 \mathrm{mg} / \mathrm{L}\right)$ and $P$. debaryanum $\left(\mathrm{EC}_{50}=74.87 \mathrm{mg} / \mathrm{L}\right)$, while $F$. oxysporum was the least sensitive to this fungicide $\left(\mathrm{EC}_{50}=194.4 \mathrm{mg} / \mathrm{L}\right)$. Dithane exhibited the highest antifungal activity against the fungus A. alternata $\left(\mathrm{EC}_{50}=54.2 \mathrm{mg} / \mathrm{L}\right)$, followed by $P$. debaryanum $\left(\mathrm{EC}_{50}=68.4 \mathrm{mg} / \mathrm{L}\right)$ and $P$. infestans $\left(\mathrm{EC}_{50}\right.$ $=76.3 \mathrm{mg} / \mathrm{L}$ ), while $F$. oxysporum was the least sensitive to this fungicide $\left(\mathrm{EC}_{50}=82.87 \mathrm{mg} / \mathrm{L}\right)$. Dicozeb caused the highest antifungal activity against the fungus A. alternata $\left(\mathrm{EC}_{50}=40.2 \mathrm{mg} / \mathrm{L}\right)$, followed by $P$. infestans $\left(\mathrm{EC}_{50}=59.08 \mathrm{mg} / \mathrm{L}\right)$ and $F$. oxysporum $\left(\mathrm{EC}_{50}\right.$ $=71.4 \mathrm{mg} / \mathrm{L}$ ), while $P$. debaryanum was the least sensitive to this fungicide $\left(\mathrm{EC}_{50}=146.17 \mathrm{mg} / \mathrm{L}\right)$. Manco showed the highest antifungal activity against the fungus A. alternata $\left(\mathrm{EC}_{50}=57.57 \mathrm{mg} / \mathrm{L}\right)$, followed by $P$. infestans $\left(\mathrm{EC}_{50}=68.5 \mathrm{mg} / \mathrm{L}\right)$ and $P$. debaryanum $\left(\mathrm{EC}_{50}\right.$ $=79.09 \mathrm{mg} / \mathrm{L}$ ), while $F$. oxysporum was the least sensitive to this fungicide $\left(\mathrm{EC}_{50}=129.14 \mathrm{mg} / \mathrm{L}\right)$. Mancozan showed the highest antifungal activity against the fungus $P$. infestans $\left(\mathrm{EC}_{50}=52.05 \mathrm{mg} / \mathrm{L}\right)$, followed by $A$. alternata $\left(\mathrm{EC}_{50}=57.21 \mathrm{mg} / \mathrm{L}\right)$ and $P$. debaryanum $\left(\mathrm{EC}_{50}=88 \mathrm{mg} / \mathrm{L}\right)$, while $F$. oxysporum was the least sensitive to this fungicide $\left(\mathrm{EC}_{50}=115.48 \mathrm{mg} / \mathrm{L}\right)$. Tridex revealed the highest antifungal activity against the fungus A. alternata $\left(\mathrm{EC}_{50}=29.9 \mathrm{mg} / \mathrm{L}\right)$ followed by $P$. infestans $\left(\mathrm{EC}_{50}=39.97 \mathrm{mg} / \mathrm{L}\right)$ and $F$. oxysporum $\left(\mathrm{EC}_{50}\right.$ $=71.4 \mathrm{mg} / \mathrm{L}$ ), while $P$. debaryanum was the least sensitive to this fungicide $\left(\mathrm{EC}_{50}=93.45 \mathrm{mg} / \mathrm{L}\right)$. In generl, Tridex induced the strongest antifungal activity against each of $A$. alternata, $F$. oxysporum and $P$. infestans, while, Dithane was the most effective fungicide against the $P$. debaryanum. It has been reported that mancozeb was highly effective in inhibiting the mycelial growth of the A. alternata (Kamble et al., 2000; Habib et al., 2007; Arshad et al., 2009; Thaware et al., 2010; Zaker and Mosallanejad 2010; Syed et al., 2012). Similar results were found on F. oxysporum (Rajput et al., 2006; Shah et al., 2006; Nisa et al., 2011). It has been observed that Dithane caused moderate growth suppressing of $F$. oxysporum (Ahmad, 2010). In addition, Shailbala and Pundhir (2008) reported that alanine methyl ester plus $64 \%$ mancozeb at $0.2 \%$ was effective in reducing $P$. infestans to a lesser extent. Suleiman (2011) reported that mancozeb completely inhibited the mycelial growth of Pythium sp. at 200 ppm.

In conclusion, the results of this study indicate that some of mancozeb commercial products are not comply with of CIPAC and WHO for wettable powers (WP) specifications. Moreover, the antifungal activity of mancozeb products was significantly differed. These variations in the antifungal activity of the products may be attributed to the type, quality and ratio of additives in formulations. Therefore, caution should be taken when choosing the products and manufactures for field applications.

\section{REFERENCES}

Ahmad, M. A., 2010. Variability in Fusarium oxysporum f. sp. ciceris for chickpea wilt resistance in Pakistan. Ph.D. Thesis. Fac. of Biol. Sci. Quaid-i-Azam Univ. Islamabad. Pakistan. pp.75.

Allen, T.W., Enebak, S.A., Carey, W.A., 2004. Evaluation of fungicides for control of species of Fusarium on longleaf pine seed. Crop Protec. 23, 979-982.

Anonymous, 1970. CIPAC HANDBOOK. Analysis of technical and formulated pesticides. Vol. 1. Published by the Collaborative Int. Pesticides Analytical Council Limited. Plant Pathology Laboratory. Hatching Green. Harpenden Hertfordshire. England.

Anonymous, 1979. Specifications for pesticides used in public health. World Health Organization (WHO), pp. 327.

Arshad, H. M. I., Khan, J. A., Naz, S., Khan, S. N., Akram, M., 2009. Grain discoloration disease complex: a new threat for rice crop and its management. Pak. J. Phytopathol. 21, 31-36.

Dillard, H. R., Johnston, S. A., Cobb, A. C., Hamilton, G. H. 1997. An assessment of fungicide benefits for the control of fungal diseases of processing tomatoes in New York and New Jersey. Plant Dis. 81, 677-681.

Finney, D. J., 1971. Probit Analysis, 3rd Ed. Cambridge Univ. Press. London. pp. 333.

Gutierrez Chapin, L. J., Wang, Y., Lutton, E., McSpadden Gardener, B. B. 2006. Distribution and fungicide sensitivity of fungal pathogens causing anthracnose-like lesions on tomatoes grown in Ohio. Plant Dis. 90, 397403.

Habib, A., Sahi, S. T., Ghazanfer, M. U., Ali, S., 2007. Evaluation of some fungicides against seed born mycoflora of eggplant and their comparative efficacy regarding seed germination. Int. J. Agri. Biol. 9, 519-520.

Kamble, P. U., Ramiah, M., Patil, D. V., 2000. Eficacy of fungicides in controlling leaf spot disease of tomato caused by Alternaria alternata (F.) Kessiler. J. Soils Crops. 10, 36-38.

Matthews, G. A., 1985. Pesticide application methods. Elsb Ed., Longman Group Ltd. England. pp. 336. 
Mookerjee, P. K., 1984. Computer-Assisted Correlation Analysis in the Development of Pesticide Formulations. In Advances in Pesticide Formulation Technology, ACS Symposium Series 254 pp. 105-119.

Niessen, H. J. 1978. Relationships between acidity/alkalinity and $\mathrm{pH}$ and their importance to pesticide specifications. Pestic. Sci. 9, 603-609.

Nisa, T. U., Wani, A. H., Bhat, M. Y., Pala, S. A., Mir, R. A., 2011. In vitro inhibitory effect of fungicides and botanicals on mycelial growth and spore germination of Fusarium oxysporum. J. Biopesticides. 4, 53-56.

Patsakos, P. G., Liapis, K., Miliadis, G. E., Zafiriou, K., 1992. Mancozeb residues on field sprayed apricots. Bull. Environ. Contam. Toxicol. 48, 756-761.

Rajput, A. Q., Arain, M. H., Pathan, M. A., Jiskani, M. M., Lodhi, A. M., 2006. Efficacy of different fungicides against Fusarium wilt of cotton caused by Fusarium oxysporum F. sp. Vasinfectum. Pak. J. Bot. 38, 875-880.

Seaman, D., 1990 Trends in the formulation of pesticides - an overview. Pestic. Sci. 29, 437-449.

Secor, G.A., Gudmestad, N.C., 1999. Managing fungal diseases of potato. Canadian J. Plant Pathol. 21, 213-221.

Shafik, M. T., Abu Elamayem, M., 1967. Formulation analysis: the effect of different storage treatments on the suspensibility, agglomeration and deterioration of surfactants of DDT water-dispersible powders. Bull. World Health Organ. 37, 687-695.

Shah, M. I., Sultan, P., Nasier, A., Williams, P., Jan, A., Sajad, M., Rehman, S., Shawl, A. S., 2006. In vitro study on effect of some fungicides viz., carbendazim, mancozeb, conjoint carbendazim mancozeb and sulphur against Fusarium oxysporum. Res. J. Microbiol. 1, 360-365.
Shailbala and Pundhir, V. S., 2008. Efficacy of fungicides and bio-agents against late blight severity, infection rate and tuber yield of potato. J. Plant Dis. Sci. 3, 4-8.

Suleiman, M. N., 2011. The in vitro chemical control of Pythium aphanidermatum, an agent of tomato root rots in the North central, Nigeria. Scientia Africana. 10, 48-54.

Syed, D. Y. N., Mengesteab, T., Robiel, N., Robiel, W., Tekle, Z., 2012. Efficacy of garlic extract and mancozeb against seed borne fungal pathogen of farmer saved sorghum (Sorghum bicolor) and groundnut (Arachis hypogaea) seeds (2010-2011). Greener J. Agric. Sci. 2, 31-36.

Thaware, D. S., Fugro, P. A., Jadhav, Y.T., Magar, S.V., Karande, R.A., 2010. In vitro evaluation of different fungicides, plant extracts and bio-agents against Alternaria alternata (Fr.) Keissler causing leaf blight of cowpea. Int. J. Plant Protec. 3: 356-360.

Topps, J. H., Wain, R. L., 1957. Investigation on fungicides III. The fungitoxicity of 3- and 5-alkylsalicylanilide and para-chloroanilides. Ann. App. Biol. 45: 506-511.

Wong, F. P., Wilcox, W. F., 2001. Comparative physical modes of action of azoxystrobin, mancozeb, and metalaxyl against Plasmopara viticola (grapevine downy mildew). Plant Dis. 85, 649-656.

Zaker, M., Mosallanejad, Z. H., 2010. Antifimgal activity of some plant extracts on Alternaria alternata, the causal agent of Alternaria leaf spot of potato. Pak. J. Biol. Sci. 13: 1023-1029.

Zambonelli, A., Zechini d' Aulerio, A., Bianchi, A., Albasini, A., 1996. Effects of essential oil on phytopathogenic fungi. Phytopathol. 144, 491-494. 


\section{الملخص العربي}

الحواص الطبيعية الكيميائية والكفاءة الإبادية ضد الفطريات لمنتجات المانكوزيب التجارية فى مصر

$$
\text { أحمد البكرى, سعاد ثُمَّمَين، فريد صبرة, شحاته قاسم, إلهام سمور , سمير عبد الجليل }
$$

بالإضافة لمبيد MHOو CIPAC باستخدام طريقة WHO، علاوة علي ذلك فإن Tridex كان الوحيد

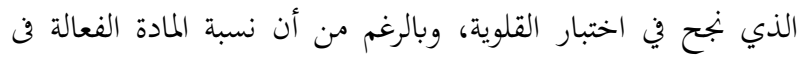
جميع منتجات المانكوزيب واحدة وهى 80\%أن فاعلية هذه المنتجات

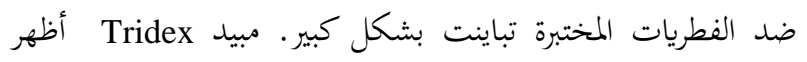

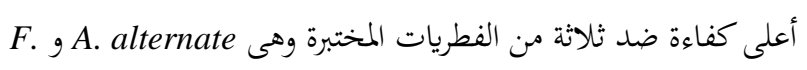
P. Infestans gxysporum

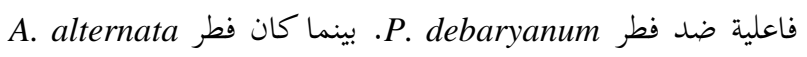

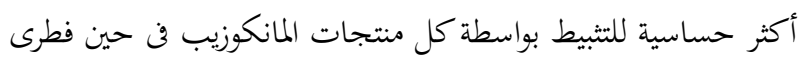

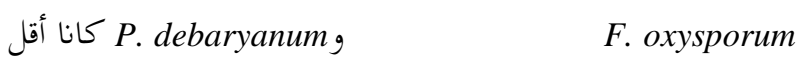
الفطريات حساسية للتبيط بهذه المنتجات. نتائج هذه الدراسة تشير إلى أن بعض منتجات المانكوزيب الموجودة في السوق المصرية غير مطابقة للمواصفات وأن الفاعلية البيولوجية تختلف بإختلاف الشركة المنتجة للمركب.
مبيد المانكوزيب هو مبيد فطرى غير جهازى واسع الإنتشار

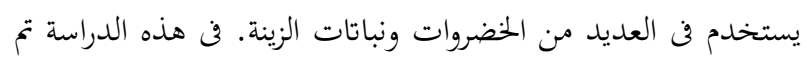
تقدير الخواص الطبيعية الكيميائية لستة من منتجات المانكوزيب التجارية المتاحة في السوق المصرية والمجهرة في صورة مساحيق قابلة

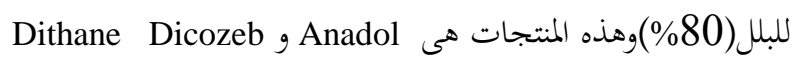

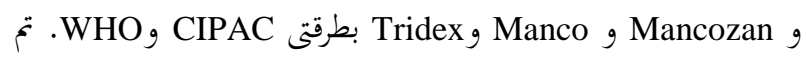

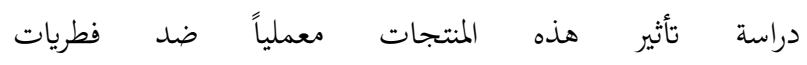
Phytophthorainfestans, Alternaria alternate وقد وقد Pythium debaryanumg Fusarium oxysporum, أظهرت النتائج أن جميع صور المانكوزيب نجحت في كلا من أختبار

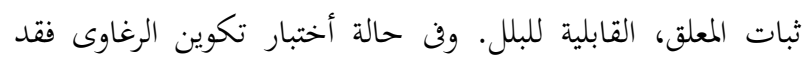
نجحت كل منتجات المانكوزيب عدا Anadol بطريقتي 